Ключові слова: жанрова форма опери, речитатив, стильові функції речитативного співу, речитативна опера, речитативний тематизм.

Chzhi In. Recitative is a factor of genre-stylish evolution of the opera work. The various compositional-dramaturgic and stylish functions of the opera recitative singing are characterized in the article, their relations with historical modifications of opera genre are opened. Direct connection of recitative form reveals with the reformative tendencies of opera work. The value of recitative is determined in opera work of the Russian composers of the end of XIX - beginning of the XX of century.

Key words: genre form of the opera, recitative, stylish functions of the recitative singing, recitative opera, recitative theme.

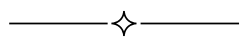

УДК 78.03+78.087.2/781.6

Aйcu

\title{
«НОВОЕ ФОРТЕПИАНО» С. ПРОКОФЬЕВА: ИСПОЛНИТЕЛЬСКИЙ И КОМПОЗИТОРСКИЙ АСПЕКТЫ
}

В статье рассмотрены причины возникновения феномена «новое фортепиано» в творчестве С. Прокофьева. Рассматриваются исполнительские особенности и композиторские нововведения, связанные с позиционированием инструмента как инструмента ударной природы.

Ключевые слова: «новое фортепиано», токкатность, ударная природа фортепиано.

Фортепианная музыка С. Прокофьева на протяжении многих десятилетий остается одной из наиболее востребованных и любимых страниц мировой фортепианной музыки, со стороны как исполнителей, так и слушательской аудитории. Однако такую заинтересованность к музыке С. Прокофьева проявляют не только исполнители, но и исследователи творчества композитора. Так, Б. Гнилов называет фортепианные концерты С. С. Прокофьева «пропастью красивой музыки» [4].

Жанр концерта для фортепиано с оркестром становится для еще молодого С. Прокофьева и творческой лабораторией, в которой оттачивались черты стиля композитора, и возможностью убедить слушательскую аудиторию в своей профессиональной состоятельности. Так, Первый фортепианный концерт композитора, увидевший свет чуть более ста лет назад, в 1912 году, становится заявлением о появлении на фортепианной сцене нового, дерзкого, но, бесспорно, талант-

(C) Айси, 2014 
ливого композитора. Следует отметить, что особую актуальность и даже уникальность, беспрецедентность, можно назвать характерной чертой жанра фортепианного концерта как отправной точки в творчестве композиторов-пианистов. Наряду с важностью жанра концерта для совершенствования творческого метода композитора, с помощью данного жанра появляется возможность существенно обновить и даже перенаправить развитие музыкального искусства в целом (яркими примерами данного утверждения может служить творчество С. Прокофьева и С. Рахманинова).

Не случайно возникла параллель с еще одним выдающимся исполнителем и композитором XX века - C. Рахманиновым. Пять фортепианных концертов С. Прокофьева (равно как и концерты С. Рахманинова) проходят «красной нитью» через все творческое и жизненное пространство композиторов, выделяя и акцентируя наиболее значительные достижения каждого.

Как указывал А. Алексеев в своей «Истории фортепианного искусства», - «среди учеников Есиповой немало известных пианистов. Крупнейший из них - C. С. Прокофьев, антипод направлению Есиповой, но немало обязанный ей - прежде всего развитием своего виртуозного мастерства. В 1910-е годы выдвинулось новое стилевое направление, резко противостоящее символизму и импрессионизму. Представленное в русской фортепианной музыке тех лет в основном сочинениями Прокофьева, оно получило интенсивное развитие в период между двумя мировыми войнами» [1]. Исследователь особо подчеркивал, что для композиторского метода С. Рахманинова особое значение приобретали динамизации музыкального развития, акцентность и равномерная ритмическая пульсация, подчеркивая, что С. Рахманинов «был великим мастером акцента, применявшим его исключительно разнообразно. Он не только обобщил в этой сфере выразительности опыт романтического искусства, но и предварил новаторскую практику композиторов нового поколения, притом таких различных по своим метроритмическим новациям, как Прокофьев и Стравинский» [1].

Как известно, время наиболее яркого и бурного развития жанра инструментального концерта в XX веке приходится на 30-е годы, и немалую роль в этом утверждении играет творческая деятельность С. Прокофьева в единстве ее исполнительской и композиторской сторон. Однако, несмотря на новые идеи в данной жанровой сфере, подобное развитие фортепианного концерта было бы просто невоз- 
можным без опоры на традиции пианизма и принципы композиции в сфере фортепианного искусства. С этой позиции роль А. Есиповой становится особо важной и значительной, так как ее воздействие на юного Прокофьева было весьма значительным.

Уже Первый фортепианный концерт демонстрирует существенное обновление музыкального языка фортепианного концерта, в котором сочеталась необычайная сложность партии солиста, блестящая виртуозность, требующая особой профессиональной подготовки, с удивительной ясностью и даже простотой музыкального языка. Этот особый юношеский задор и принципиальный уход от концепции философского осмысления человеческой жизни в музыке закреплен во многих исследованиях, посвященных творческому наследию С. Прокофьева в понятии «детскости» [6].

Во Втором фортепианном концерте композитор предлагает испытать вместе с его музыкой широкий диапазон эмоциональных состояний - от мечтательно-созерцательных тонов до мощного патетического. Однако бесспорной вершиной в развитии жанра фортепианного концерта в творчестве С. Прокофьева, некоей кульминацией становится Третий фортепианный концерт (1923). В сочетании с приоритетом традиционных для жанра фортепианного концерта методов развития это произведение буквально пронизано парадоксальными контрастами, где вполне привычная распевность неожиданно переходит в сухую токкатность, создавая порой ощущение издевки, сарказма. Вместе с тем важно отметить, что это не исключает наличие особой прокофьевской лирики, которую, как сожалел сам композитор, зачастую просто не замечали. И даже более того, на протяжении многих лет прокофьевской музыке в лирике было отказано вовсе. И словно опровергая это убеждение, прокофьевские фортепианные произведения тридцатых-сороковых годов XX века знаменуют поиск новой лирики в ее сопряжении с новым фортепианным стилем.

Как справедливо указывает Е. Симонянц в своем диссертационном исследовании [7, с. 6], глашатаями нового фортепианного стиля, возникновение которого она связывает с ударно-токкатной трактовкой фортепиано, становятся С. Прокофьев и И. Стравинский в России, Б. Барток - в Венгрии, П. Хиндемит - в Германии. Среди наиболее важных сочинений названных композиторов, которые совершенно изменили представление о природе фортепиано и убедительно продемонстрировали его ударно-токкатные возможности, 
можно назвать «Наваждение», Токкату, фортепианные концерты 10-х годов С. Прокофьева; «Петрушку» И. Стравинского, «Allegro barbaro», «Out of doors» Б. Бартока, сюиту «1922 год» П. Хиндемита и др. Естественность вхождения эстетики токкатности в пространство фортепианного искусства многие исследователи связывают с феноменом звонов, его поэтикой и семантикой в творчестве многих композиторов - от М. Мусоргского, до С. Рахманинова.

Таким образом, эстетическое основание нового стиля фортепианного искусства, или эстетики «нового фортепиано» получает мощную поддержку в лице многих композиторов, приводя к ударной трактовке фортепиано, и как следствие - к новому художественному результату. Развитие указанных тенденций приводит к еще более любопытным результатам, нашедшим свое выражение в творчестве композиторов-«шестидесятников», причем в жанровом отношении пристальное внимание уделяется снова концерному жанру.

Концерт продемонстрировал способность воплотить и выразить наиболее востребованные и актуальные проблемы, волнующие композиторов и их современников, мысль об опустошенности, оставленности и об особом драматическом переживании жизненного момента, наполненном протестными эмоциями. На этом пути прокофьевское «новое фортепиано» и особая эмоционально заостренная токкатность приобретает значение некоего эталона и стилевого ориентира.

Среди музыковедческих исследований, затрагивающих изучение фортепианного искусства XX века, можно назвать много новых работ, со смелыми гипотезами. Однако следует отметить, что неизменной базой всех новых исследований остается ставшая хрестоматийной работа М. Друскина «Новая фортепианная музыка» [5], изданная еще в 1928 г. Тонкое музыкальное чутье и особый аналитический подход позволили исследователю прийти к ряду заключений о природе и особенностях «нового фортепиано», дали возможность охарактеризовать это явление. В поиске объяснения возникновения феномена «нового фортепиано» М. Друскин приходит к выводу, что она коренится в природе самого инструмента. Не случайно в блестящем предисловии к этой книге И. Глебов настаивает на термине «фортепианность», а не «пианизм», а Л. Гаккель в своей работе «Фортепианная музыка XX века: Очерки» рассматривает «образ» фортепиано XX столетия, особо подчеркивая звуковую природу инструмента и ее новую трактовку в композиторском творчестве первой половины XX века. 
Все это обусловило возникновение ряда близких трактовок композиторской стилистики в контексте общей парадигмы «нового фортепиано», а именно - токкатно-ударное восприятие рояля современными композиторами, токкатно-ударный исполнительский стиль, синонимичный ему токкатно-ударный пианизм и токкатно-ударная техника [7]. При этом необходимо отметить, что конечный художественный результат все же зависит от композиторского видения, от его эстетических представлений, а потому поиски и открытия в сфере токкатно-ударного пианизма не утратили своей актуальности и во второй половине XX - начале XXI в.

Любопытно, что трактовка «нового фортепиано» с его ударной природой оказала существенное воздействие и на другие инструменты. В этом новом для них качестве предстают инструменты струнной группы, природа которых исключительно певуча. Однако в XX веке происходит трансформация исполнительского приема col legno, введенного композиторами-романтиками как специфической звукоизобразительной краски. Данный прием приобретает новое прочтение и исполняется как удар по струнам древком смычка, но фортепиано, конечно, принадлежит первенство в отношении усиления ударных свойств инструмента, вплоть до функции ударной группы в оркестровом tutti. Ярким примером этого может служить кульминация финала Симфонии № 2 С. Прокофьева.

Иными словами, если в эпоху романтизма композиторами, работающими в сфере фортепианного искусства, максимально преодолевалась ударная природа фортепиано, а инструмент наделялся вокальными качествами, то в первой половине XX века наблюдается обратная тенденция. Создается продолжительный ряд фортепианных сочинений, характер исполнения которых, равно как и музыкально-образная сфера, находились в прямом соотношении с ударными функциями «нового фортепиано», что в свою очередь обусловило появление совершенно новых приемов звукоизвлечения, базирующихся на принципе токкатности.

Вместе с тем, обновленный исполнительский арсенал и изобретение новых приемов звукоизвлечения были мало применимы к произведениям эпохи романтизма. Об этом предупреждал и предостерегал выдающийся педагог С. Фейнберг, который указывал, что «сильный фортепианный удар, сопровождаемый быстрым затуханием звука, не способствует мелодическому восприятию и даже оказывает обратное воздействие, лишая фразу напевности» [9, с. 242]. В. Чинаев 
продолжает мысль С. Фейнберга и говорит о том, что обновленные принципы исполнительства, связанные с эстетикой «нового фортепиано», являются оппозицией по отношению к романтической манере исполнения. Он отмечает: «...нонлегатность, ударность, острая контрастность исполнительских средств, бескомпромиссная игра чистых звуковых форм...» [10, с. 339.].

Таким образом, отсутствие певучести, плавности звучания фортепиано становится в некотором смысле целью, а ограниченность дления фортепианного звука, обусловленная конструктивными особенностями инструмента, уже не смущает ни композиторов, ни исполнителей. На эту тенденцию в творчестве С. Прокофьева указывал Л. Гаккель, когда говорил, что композитор стремился в своем творчестве использовать «краткозвучность» фортепиано для достижения определенных выразительных эффектов, то есть фортепиано именно в этом качестве становилось воплощением художественных замыслов композитора. Однако «в этом своем стремлении, восходящем к долистовским временам, Прокофьев расходился с традициями русского пианизма Рубинштейна - Чайковского - Рахманинова - c одной стороны, с традициями романтического пианизма - с другой» [3, c. 67].

XX век рассматривает полутоновую структуру фортепиано, которую ранее пытались смягчить с помощью педали и мягкого звукоизвлечения, как положительную черту, позволяющую инструменту выделяться на фоне инструментов с нефиксированной полутоновостью. Это позволяло особо подчеркнуть токкатную и ударную природу фортепиано. По мнению М. Тараканова, эти качества фортепиано позволяли ему особо выгодно выглядеть в сопоставлении партии солиста и оркестра в традиции концертного жанра. «Именно интонационная отчетливость, присущая линиям и созвучиям фортепиано, делает его способным «пробить» фон и утвердить свою гегемонию» [8, с. 215].

Развитие ритмики как художественного феномена способствовало усилению ударных, перкуссионных функций инструмента. Подчеркнутая ритмическая ясность и четкость звучания способствуют выделению остроты ритмических формул, не предусматривающих слитности, легатности звучащего музыкального материала, иными словами - штрих legato уступает место бузониевскому non legato. Обозначенная тенденция во многом коренилась в принципе токкатного звукоизвлечения, которое демонстрировал в собственном исполнительстве и композиторском творчестве С. Прокофьев. Таким обра- 
зом, в результате всех этих изменений слитное горизонтальное выражение мелодии сменяется опорой на вертикаль, причем не только в качестве технического приема, но и как формы, которая также становится подвластной ритмической стихии, достигающей своего апогея в характерных прокофьевских ритмических остинатных формулах.

\section{СПИСОК ЛИТРАТУРЫ}

1. Алексеев А. История фортепианного искусства : в 3 ч. / А. Алексеев. М. : Музыка, 1982. - Ч. 3. - 286 c.

2. Гаккель Л. Фортепианная музыка XX века : Очерки / Л. Гаккель. - 2-е изд., доп. - Л. : Сов. композитор, 1990. - 288 с.

3. Гаккель Л. Фортепианное творчество С. С. Прокофьева / Л. Гаккель. М. : Госмузиздат, 1960. $-172 \mathrm{c}$.

4. Гнилов Б. Фортепианно-оркестровая композиция в свете личностной концепции культуры / Б. Гнилов // Развитие личности : для профессионалов науки и практики. - М. : Народное образование, 1997. - С. 70-83.

5. Друскин М. Новая фортепианная музыка / М. Друскин. - Л., 1928. $111 \mathrm{c}$.

6. Немировская И. Феномен детства в творчестве отечественных композиторов второй половины XIX - первой половины XX веков : дис. ... Д-ра искусствоведения : специальность 17.00.02 - музыкальное искусство / Иза Абрамовна Немировская. - Магнитогорск, 2011. - 229 с.

7. Симонянц Е. Токкатно-ударная трактовка рояля в фортепианных концертах отечественных композиторов второй половины XX - начала XXI столетий : дисс. ... канд искусствоведения: специальность 17.00.02 - музыкальное искусство / Елена Михайловна Симонянц. - М., 2014. - 244 с.

8. Тараканов М. Творчество Родиона Щедрина / М. Тараканов. - М. : Советский композитор, $1980 .-331 \mathrm{c.}$

9. Фейнберг С. Е. Пианизм как искусство / С. Е. Фейнберг. - М. : Музыка, $1969 .-598$ с.

10. Чинаев В. П. Исполнительские стили в контексте художественной культуры XVIII-XX веков: дис. ... Д-ра. искусствоведения : специальность 17.00.02 - музыкальное искусство / Владимир Петрович Чинаев. - М., 1995. $-654 \mathrm{c}$.

Aїсі. «Нове фортепіано» С. Прокоф’єва: виконавський та композиторський acneкти. У статті розглянуто причини виникнення феномена «нове фортепіано» у творчості С. Прокоф’єва. Розглядаються виконавські особливості та композиторські нововведення, пов'язані з позиціонуванням інструменту як інструменту ударної природи.

Ключові слова: «нове фортепіано», токатність, ударна природа фортепіано. 
Aysi. «New piano» by S. Prokofiev: performance and composing aspects. The article deals with the causes of the phenomenon of «new piano» in the works of S. Prokofiev. On the performance characteristics and compositional innovations related to the positioning of the tool as a tool for the shock of nature.

Key words: «New piano», principle of toccata, impact nature of the piano.

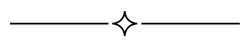

УДК 78.03+78.083.1

\section{Цзян Маньни}

\section{ПРИЗНАКИ ЦИКЛИЧНОСТИ СЮИТЫ «ОБРАЗЫ» ДЛЯ ФОРТЕПИАНО КЛОДА ДЕБЮССИ}

В статье рассматривается сюита Клода Дебюсси «Образы» с точки зрения наличия цикличности и самостоятельности двух серий пьес (по три). Выявляются черты как самостоятельности, так и индивидуальности, каждой из пьес сюиты. А также анализируются и определяются целый ряд различных общностей (монотематизма, программных, лейтобразных, лейтинтонационных, лейтмотивных, гармонических, фактурных и др.) между пьесами «Образов». И таким образом делается вывод о несомненной цикличности сюиты Дебюсси «Образов».

Ключевые слова: иикл, самостоятельность, программность, монотематизм, лейтинтонация, лейтмотив, лейттема, лейтгармония, лейтфактура.

В 1905 году композитором создается первая серия фортепианного цикла «Образы» (Images): «Отражения в воде», «Посвящение Рамо» и «Движение». И уже через два года - вторая серия «Образов»: «Колокольный звон сквозь листву», «И луна спускается на место, где некогда был храм» и «Золотые рыбки». Отметим интересное явление: все эти сборники фортепианных циклов состоят из трех пьес. Тенденция создания именно трех пьес, собранных в одну серию под общим названием, - характерная особенность творчества Дебюсси. Впервые она выявилась в других, не фортепианных, жанрах: в романсах Дебюсси - «Три мелодии», 1891: где первая серия содержала «Галантные празднества», 1892; «Песни Билитис», 1807); а вторая серия «Галантных празднеств», 1904 (на слона Верлена), состоящая также из трех романсов, содержала: «Наивные», «Фавн» и «Сентиментальный разговор». Вместе с тем, вторая серия пьес «Три мелодии» отличается от первой не только выбором текстов, но и их трактовкой, а также ис-

(C) Цзян Маньни, 2014 